University of Nebraska - Lincoln

DigitalCommons@University of Nebraska - Lincoln

USGS Staff - Published Research

US Geological Survey

2009

Cahokia's Boom and Bust in the Context of Climate Change

Larry Benson

U.S. Geological Survey, great.basin666@gmail.com

Timothy R. Pauketat

University of Illinois at Urbana-Champaign, pauketat@illinois.edu

Edward R. Cook

Lamont-Doherty Earth Observatory, drdendro@ldeo.columbia.edu

Follow this and additional works at: https://digitalcommons.unl.edu/usgsstaffpub

Benson, Larry; Pauketat, Timothy R.; and Cook, Edward R., "Cahokia's Boom and Bust in the Context of Climate Change" (2009). USGS Staff -- Published Research. 724.

https://digitalcommons.unl.edu/usgsstaffpub/724

This Article is brought to you for free and open access by the US Geological Survey at DigitalCommons@University of Nebraska - Lincoln. It has been accepted for inclusion in USGS Staff -- Published Research by an authorized administrator of DigitalCommons@University of Nebraska - Lincoln. 


\title{
CAHOKIA'S BOOM AND BUST IN THE CONTEXT OF CLIMATE CHANGE
}

\author{
Larry V. Benson, Timothy R. Pauketat, and Edward R. Cook
}

\begin{abstract}
During the early Mississippian Lohmann phase (A.D. 1050-1100), the American Bottom experienced a political and economic transformation. This transformation included the abrupt planned construction of central Cahokia, a large-scale influx of people to "downtown Cahokia," the abandonment of pre-Mississippian village settlements, the reorganization of farming in the Mississippi River floodplain, and the founding of the Richland farming complex in the Illinois uplands. New treering-based records of climate change indicate that this rapid development occurred during one of the wettest 50-year periods during the last millennium. During the next 150 years, a series of persistent droughts occurred in the Cahokian area which may be related to the eventual abandonment of the American Bottom. By A.D. 1150, in the latter part of a severe 15-year drought, the Richland farming complex was mostly abandoned, eliminating an integral part of Cahokia's agricultural base. At about the same time, a 20,000-log palisade was erected around Monks Mound and the Grand Plaza, indicating increased social unrest. During this time, people began exiting Cahokia and, by the end of the Stirling phase (A.D. 1200), Cahokia's population had decreased by about 50 percent and by A.D. 1350, Cahokia and much of the central Mississippi valley had been abandoned.
\end{abstract}

Durante la fase temprana del Lohmann Mississíppico (A.D. 1050-1100), el American Bottom se transformó política y económicamente. Esta transformación incluyó la rápida planeación de la construcción de Cahokia, una llegada masiva de gente al su centro, el abandono de los asentamientos de villas pre-Mississíppicas, la reorganización de la agricultura en las partes bajas del río Mississippi y la fundación del complejo agrícola Richland en la tierras altas de Illinois. Nuevos registros de cambio climático, basados en anillos de árboles, indican que este rápido desarrollo ocurrió durante uno de los más húmedos períodos de 50 años del último milenio. Durante los 150 años siguientes, una serie de sequías persistentes ocurrieron en el área de Cahokia, lo que debe relacionarse con el abandono del American Bottom. Para 1150 A.D., en la última parte de una severa sequía de 15 años, el complejo agrícola Richland fue casi abandonado, eliminando una parte integral de la base agrícola de Cahokia. Casi al mismo tiempo, una palizada de 20,000 estacas fue levantada alrededor de Monks Mound y la Grand Plaza, indicando el incremento de conflictos sociales. Durante este tiempo, la gente empezó a salir de Cahokia y, para fines de la fase Stirling (1200 A.D.), la población de Cahokia había decrecido cerca del 50 por ciento; para 1350 A.D., Cahokia y gran parte del valle central del Mississippi habian sido abandonados.

$\mathrm{R}$ ecent studies have indicated a renewed interest in the possible influence of climate change on precolumbian cultures (e.g., Anderson et al. 2007; Benson, Petersen, and Stein 2007; Benson, Berry, Jolie, Spangler, Stahle, and Hattori 2007; Cook et al. 2007; Drysdale et al. 2006; Gill 2000; Hodell et al. 1995; Jones et al. 1999; Kennett and Kennett 2006; Stahle et al. 2000). Benson, Berry, Jolie, Spangler, Stahle, and Hattori (2007) have suggested that mid-twelfth- and late-thirteenth-century decadal-scale droughts may have impacted Native Americans across much of the contiguous United States. If true, this might not only help explain the historical trajectories of the ancestral Pueblo in the Four Corners area of the western United States, but it might also elucidate the factors underlying the rise and fall of the Cahokians in what is now west-central Illinois.

In a recent paper, Benson, Petersen, and Stein (2007) compared precolumbian Southwestern

Larry V. Benson $\square$ National Research Program, U. S. Geological Survey, 3215 Marine St., Boulder, CO 80303 (lbenson@usgs.gov)

Timothy R. Pauketat $\square$ Department of Anthropology, 109 Davenport Hall, University of Illinois, Urbana, IL 61801

Edward R. Cook $\square$ Biology and Paleo Environment, Lamont-Doherty Earth Observatory, 61 Route 9W, P.O. Box 1000, Palisades, NY 10964 
demographic change with tree-ring-based drought histories for the Four Corners region, reinforcing the conjectures of Judge (1989) and Douglass (1929) that the middle-twelfth- and late-thirteenthcentury droughts led to ancient migrations. In this paper, we focus on the relationship of the culturaldemographic oscillation of the ancient Cahokia region to new tree-ring-based records of climate change. In the following, we first review the cultural processes that attended the rise and fall of Cahokia. We then illustrate and discuss tree-ringbased records of climate change for the region surrounding Cahokia. Last, we compare those records of climate change with the cultural history of Cahokia, demonstrating that Cahokia's "boom" phase occurred during one of the wettest 50-year periods in the past millennium and that its "bust" phase occurred during a series of intense and persistent droughts.

\section{Cahokian Expansion and Agricultural Reorganization}

After the mid-eleventh century, Cahokia was the centerpiece of a large central politicaladministrative complex that also included the present sites of St. Louis (Mound City) and East St. Louis (Figure 1, see also Pauketat 2004). This entire complex now seems the product of a political and economic expansion that occurred immediately prior to and in the decades following A.D. 1050 (Table 1). This development saw the abrupt planned construction of central Cahokia centered on a single massive $6.5 \mathrm{~m}$-high platform (the core of Monks Mound) and the Grand Plaza (Dalan et al. 2003). At the same time, the region saw a large-scale influx of people to "downtown Cahokia," the concomitant abandonment of pre-Mississippian village settlements in the Mississippi River floodplain, the simultaneous dissolution of pre-Mississippian courtyards at Cahokia, and the founding of the Richland farming complex in the Illinois uplands (Alt 2002; Emerson 1997a, 1997b; Lopinot et al. 1998; Pauketat 1994, 1997, 1998a, 2000, 2003; Pauketat and Lopinot 1997). We also suspect that an agricultural reorganization accompanied this societal transformation, an argument that rests partially on regional population size and disposition.

Although there are several population estimates for Cahokia and its immediate environs, two efforts have made use of the most recent data on building density at or around Cahokia. On the one hand, Milner $(1986,1998)$ estimated the Mississippianperiod population of a 129 square $\mathrm{km}$ portion of the rural American Bottom and also for Cahokia proper. On the other hand, Pauketat and Lopinot (1997) calculated Cahokia's pre-Mississippian and Mississippian-period population using structure density/phase data from analyzed excavation tracts (15A and ICT-II).

With regard to Milner's rural estimate, the numbers and floor areas of residential structures at 15 sites indicate that the highest rural population density dated to the Stirling phase (Milner 1986). His later calculations of Cahokia's population were based on average structure densities from several excavated tracts at the site, some of which had yet to be analyzed. Assuming that each building stood only five to ten years and was occupied by four to five people, his estimates "in the low thousands" reveal a Lohmann phase population peak (Milner 1998:122-124).

By comparison, Pauketat and Lopinot's (1997) estimate, which applies only to a $1.8 \mathrm{~km}^{2}$ highdensity occupation area of Cahokia, shows that the site's population increased from $1,400-2,800$ people during the 50-year Edelhardt phase to $10,200-15,300$ people during the subsequent 50 year Lohmann phase. After the Stirling phase, densities declined. ${ }^{1}$ Later, Pauketat (2003:47) also estimated the population of the outlying Richland rural farming district, covering about 300 square $\mathrm{km}$, based on numbers of sites and excavated buildings per phase. The results of this effort indicate isolated peak populations for that locality of between 3,000 and 7,400 people during the late Lohmann and early Stirling phases. Both estimates show that the region's peak population falls within the Lohmann and Stirling phases. Moreover, from either point of view, the lower population estimates for Cahokia may be seen as "consistent with the numbers of people who could have been supported in this floodplain setting with the primitive technology of that time" (Milner 1998:123). Cahokia, after all, is situated in the middle of the widest part of the American Bottom's broad expanses of relatively high well-drained land suitable for growing crops, a locality also rich with resources derived from permanent swamps and lakes (Milner and Oliver 1999). Fish, which were readily available in 


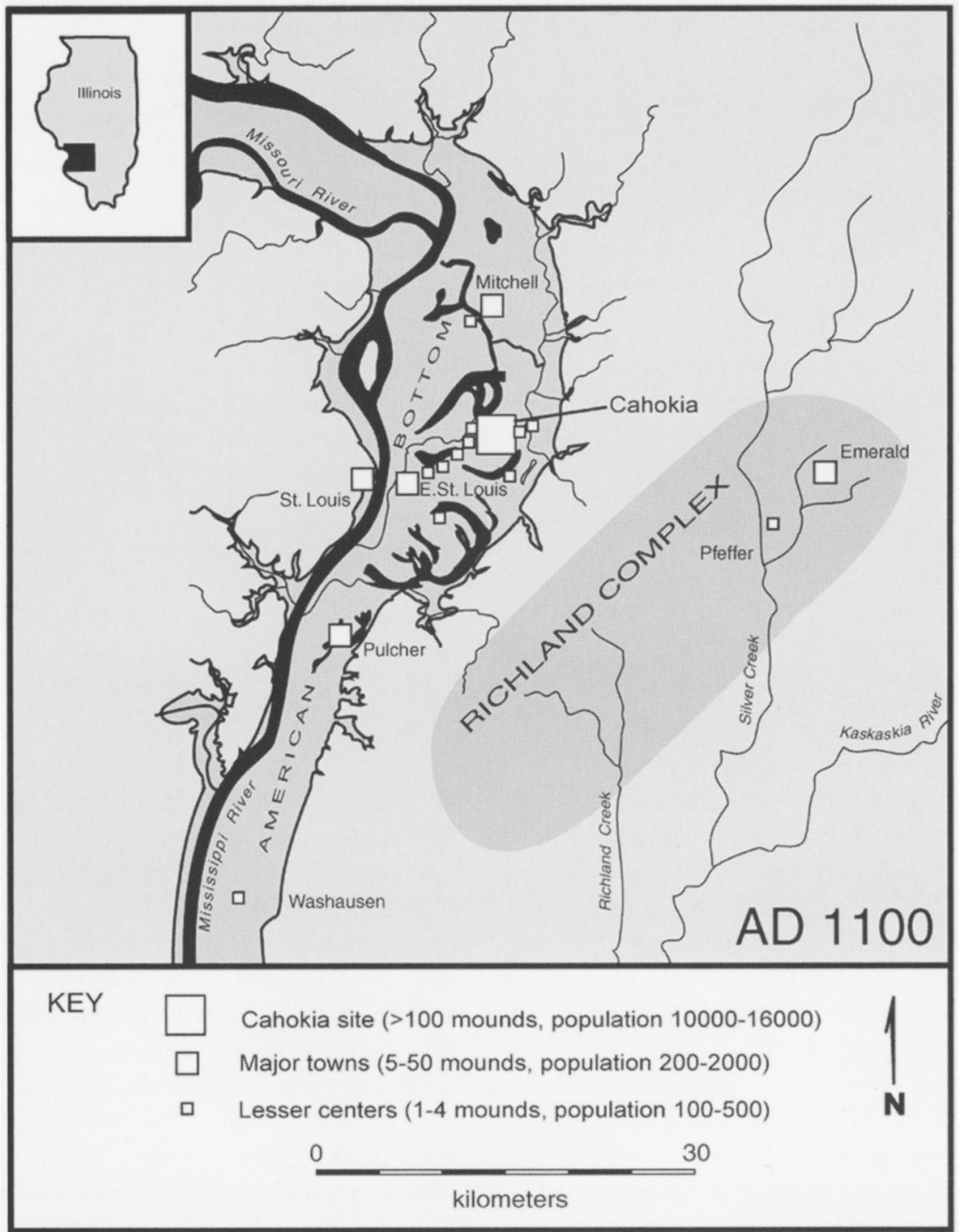

Figure 1. Major settlements in the greater Cahokia area at about A.D 1100. After Figure 6.4 in Pauketat (2007).

backwater and creek locations within the American Bottom, were a critical component of the Cahokian diet (Cross 1987; L. S. Kelly 1997). The American Bottom surface-water systems were also home to abundant waterfowl (Kelly and Cross 1984).

And yet, as Milner (1998) and others have argued, despite the resource richness of the American Bottom, precolumbian subsistence productivity might have been an issue of great concern to Cahokians and rural Mississippian farmers. In most other regions of eastern North America, the risks of Mississippian-style agricultural production were high (see Scarry 1993a, 1993b). The potential impacts of crop failure on local economies and political organizations were great (Anderson et al. 1995; Stahle and Cleaveland 1994). Once intensified after A.D. 800, a whole new suite of maizerelated agricultural and technological exigencies likely made themselves apparent (Maher 1989; Johannessen 1984; Riley et al. 1994; Rindos and Johannessen 1991). 
Table 1. Archaeological Chronology and Inferred Organizational Attributes for the Later Pre-Columbian American Bottom Region.

\begin{tabular}{|c|c|c|c|}
\hline Period & Phase* & Years A.D. & Regional-Organizational Attributes** \\
\hline \multicolumn{4}{|c|}{ Terminal Late Woodland } \\
\hline & Loyd & $900-950$ & low regional population density, Cahokia is probably an ordinary village \\
\hline & Merrell & $950-1000$ & $\begin{array}{l}\text { low regional population density, Cahokia village is first among equals, now includes } \\
\text { uncertain number of immigrants modest regional population density, immigration } \\
\text { continues, Cahokia assumes town-sized proportions but retains pre-Mississippian } \\
\text { courtyard }\end{array}$ \\
\hline & Edelhardt & $1000-1050$ & organization \\
\hline
\end{tabular}

Mississippian

Lohmann 1050-1100 highest regional population density, large-scale influx of immigrants, reconstruction of Cahokia according to new city plan, abandonment of pre-Mississippian settlement organization

Stirling $\quad 1100-1200 \quad$ sustained to slightly lower population density, homogenization of material culture, elaboration of ritual-administrative complex

Moorehead 1200-1275 reduced population density, political-economic contraction or reorganization, palisade wall construction

Sand Prairie $1275-1350$ low regional population density, culmination of regional emigration, abandonment

*following Fortier et al. 2006

**see Alt 2002; Emerson 1997a; Holley 2006; J.E. Kelly 1990; Milner 1986; Pauketat 1998a, 2003, 2004, 2005

Certainly, the higher population estimates for the American Bottom region, above, would have accentuated such subsistence productivity issues. Even in recent times in the American Bottom, Euroamerican farmers who began their careers farming during the 1920s and 1930s, interviewed by Chmurny in 1967, were of the uniform opinion that "scarcely a year passed in the Bottom without the occurrence of some weather phenomena, usually unwelcome" (1973:243). Those who survived over the long run were those that "divided their risks," often "at the expense of increased inefficiency and lessened gains," by planting a diversity of crops in both "well-drained and poorly-drained" soils (Chmurny 1973:247-248). Projecting similar strategies and conditions into the past, Milner concluded that, for ancient farmers, the "overall picture could have been nothing other than gloomy during much of the Mississippian period, despite the richness of the valley. The inhabitants of the American Bottom were perched on the cusp between success and failure, and a series of bad years would have been disastrous for them" (1998:78).

Prior to A.D. 1050, such subsistence production concerns might have been less problematic for indigenous farmers. At that time, most analysts would agree, the political and community order in the American Bottom had not transcended the constraints of isolated Mississippi River floodplain localities (cf. J.E. Kelly 1990; Milner 1998; Pauketat 2004). Isolated single-home farmsteads were few and far between and villages or hamlets occupied high floodplain ridges and the bluff edge of the American Bottom (e.g., Emerson and Jackson 1984; J. E. Kelly 1990; Pauketat et al. 1998). Houses in these settlements, small semisubterranean pole-and-thatch huts with floors half-ameter or more below ground level, were often arranged around courtyards, each centered on a modest central marker post. The pre-Lohmann phase rural settlements in the American Bottom reveal little-to-no internal status differentiation, political specialization, communal activities, or ranking (see Holley 2006; J. E. Kelly 1990; Pauketat 1994).

It was not until the Lohmann phase that regional-organizational shifts can be inferred from settlement, monument-construction, and refusedeposition data that probably correlate with the appearance of a centrally managed agricultural system. In the American Bottom floodplain proper, the Mississippian transition correlates with abandonment of some if not many preMississippian villages and their replacement by small farmsteads and large towns (Emerson 
1997a, 1997b; Mehrer 1995; Milner et al. 1984). All evidence to date suggests that, whether a large town or small farmstead, the once-common preMississippian courtyard group-single-post houses set around an open space with a central marker post-disappeared rather quickly (Pauketat 1994:131-133; see also Emerson 1997a; Mehrer 1995; Mehrer and Collins 1995; Milner et al. 1984).

Emerson (1997a, 1997b) has argued that the subsequent rural "dispersed communities" in the floodplain were articulated to larger towns and, ultimately, to Cahokia via special "nodal" farmsteads. At these sites, there are new forms of ritual or special-purpose architecture and the residues of various ceremonial practices most like those known from Cahokia itself. Thus, Emerson has further argued, based on their unprecedented appearance during the Lohmann phase and because of their special architecture and artifacts, such nodal farmsteads were the "direct product of Cahokian elite intervention" (1997a:250). Some time nearing the mid-eleventh century, the floodplain

countryside about the great mound center of Cahokia was emptied of its rural populations, presumably because these people moved to larger nucleated centers. With the onset of the Lohmann phase, a new system of dispersed farmsteads and controlling nodal centers was superimposed across this depopulated landscape.... I have argued, given the large Lohmann and Stirling phase populations at Cahokia, that this rural organization was designed to intensify the production and mobilization of staples to support the centers [Emerson 1997a:250].

With additional survey and excavations since the 1990s, we know also know that, as part of this region-wide reorganization, an extensive upland agricultural landscape (the Richland farming complex) was established in the loess-covered hills east of Cahokia proper (Alt 2001, 2002; Pauketat 2003) (Figure 1).

Prior to the Lohmann phase, there were no settlements of any kind across large areas of these uplands. Afterward, however, a series of towns, villages, hamlets, farmsteads, and other special sites appeared where none had been previously, especially in the Richland and Silver Creek drainages
(Alt 2001, 2002; Koldehoff 1989; Pauketat 2003).

Richland and other upland farmers may have been derived from pre-Mississippian settlements on the Mississippi floodplain or from sites in the interiors of Illinois, Missouri, or Indiana (Alt 2002). Radiocarbon dates together with ceramic and lithic markers indicate that the upland complex dates primarily from A.D. 1050 to 1150 with only a few buildings dating to the latter years of the Edelhardt phase (Pauketat 2003). By about A.D. 1100, each of the eight largest settlements in the Richland farming complex was occupied, suggesting that the regional population at the time was considerably larger than some earlier estimates that considered only the flood plain itself (e.g., Milner 1998:120, 124-125; see also Schroeder 2004).

Judging from archaeobotanical remains and lithic-tool debris these were, first and foremost, agricultural villages. At these sites, as at other locations in the central Mississippi valley, Mill Creek chert hoe blades and the debitage from the resharpening of the same are common indicators of agricultural activity (Cobb 2000; Sussenbach 1993). They are certainly prevalent at most late preMississippian and Mississippian sites in the American Bottom region.

Mill Creek hoe blades may have been a tool especially necessary for the initial working of the heavily rooted soils of the upland prairie or prairieforest ecotone, located near most of the Richland complex sites (Pauketat 2003). In fact, around Cahokia during the Lohmann phase, the density of hoe-blade resharpening flakes in excavated domestic refuse indicates that the rate at which the tools were used and resharpened increased with distance from Cahokia at the same time that other item densities decreased. That is, the

distribution of craft products and the availability of Cahokian subsidies or the exotic raw material ... consistently falls off in the surrounding northern floodplain, decreasing further still as one moves out in the Richland Complex.... Conversely, the density [grams/cubic meter of domestic refuse] of Mill Creek chert hoe-blade fragments and resharpening flakes increases with distance from Cahokia to a Richland Complex peak. In other words, all other things being equal, access to Cahokian valuables and craft objects seems to have been inversely related to the intensity of 
agricultural production using hoe blades

[Pauketat 1998a:68-69, emphasis added].

Other upland areas in Illinois and Missouri, within a $50 \mathrm{~km}$ radius of Cahokia, may have been intensively farmed as well after A.D. 1050; systematic archaeological surveys of this region have not been sufficiently extensive to identify the full range of Lohmann and Stirling phase sites either along the Kaskaskia River to the east or the lower Missouri River to the west (Blake 1955; Hargrave et al. 1983; Harl 1991; Hunt 1974; Kuttruff 1972). In any event, the unprecedented Richland complex occupation of the uplands-thousands of possible immigrants and other resettled farmers-may be related to their proximity to highly productive prairie and prairie-edge soils at the headwaters and interfluves of Richland and Silver Creeks. The tallgrass prairie was so nitrogen rich that fertilizers were not needed to sustain a luxuriant crop for some time; sometime prior to A.D. 1860, a traveler noted that "I saw fields of maize that have been grown for 30 years and that, too, without any fertilizer" (Sutton 1976: 202). These soils contained so much nitrogen that early Illinois farmers found prairie soil too rich to grow wheat (Welch 1979:10), and in later times, nitrate poisoning of livestock was a widespread problem (Davidson et al. 1941). During the 1800 s a drought that killed corn in midseason allowed the plant stalks to accumulate nitrogen to the point that they "burned rapidly like the fuse of a fire cracker" (Mayo 1895:5). Indeed, such soils are closer here to Cahokia than anywhere else in the region. Such proximity may not have been lost on Cahokians, as Alt (2006) has recently noted by her identification of a "nodal village" or "ritual outpost" of Cahokia in the form of the oddly compact multi-building hilltop site of Grossmann. When excavated in its entirety, this site, located 16 $\mathrm{km}$ east of Cahokia in the midst of the Richland complex, produced evidence of atypical ritual events and Cahokia-style architecture and artifacts (Alt 2002, 2006). Based on such findings, along with the artifact-density patterns noted above, it seems plausible that the Richland complex may well have been an organized farming district, ministered to or administered by Cahokians.

One might even suspect that a populous Richland farming complex may have been an integral aspect of the early Mississippian reorganization of agricultural production in the region. The role of the Richland farmers in such a Cahokia-centered process could have been to increase the productive output of the region through regional extensification. Such extensification might have been necessary, the productive potential of floodplain in the immediate vicinity of Cahokia possibly not being sufficient to provide food for a Lohmann-phase population of more than "a few thousand inhabitants." Schroeder's (1999) revised productivity estimates for precolumbian North American maize production also supports an argument, still tentative, that a Cahokian population of 10,000 or more people during the Lohmann phase might have had difficulty feeding themselves, particularly in bad years, without the Richland complex producers (see also Pauketat 2003:48).

\section{Depopulation of the American Bottom and Abandonment of the Richland Farming Complex}

After the Lohmann phase, the population of the Cahokia region decreased as some residents appear to have relocated elsewhere. Between 5,200 and 7,200 people are estimated to have occupied Cahokia during the twelfth-century Stirling phase, dropping to between 3,000 and 4,500 people during the thirteenth-century Moorehead phase (Pauketat and Lopinot 1997). Settlement patterns also changed, with late Stirling- and Mooreheadphase houses becoming increasingly clustered into house lots (Collins 1997; Mehrer and Collins 1995; Pauketat 1998b).

Whereas the rural population on the Mississippi River floodplain proper appears to have increased slightly during the twelfth century (Milner 1998), by the late Stirling phase (A.D. 1150-1200) almost all Mississippian sites in the Richland farming complex were abandoned (Pauketat 2003). In addition, Stirling-phase sites in the American Bottom were located at lower elevations than earlier Lohmann and later Moorehead sites (Emerson 1992). This might suggest that a relative drop in the water table accompanied the cultural changes of the times, a concept supported by zooarchaeological data that indicate fewer fish remains associated with Stirling-phase sites (L.S. Kelly 1997). Possibly some or most of the American Bottom's lakes and sloughs desiccated during the twelfth century. By the Moorehead phase, 
the rural population density, in the flood plain, dropped sharply (Milner 1986).

It seems that, during the twelfth century, the "increasingly top-heavy economy and the monument-laden spaces of Cahokia grew out of proportion to the shrinking farming population" (Pauketat 2004:152). There are signs of alterations in the central appropriation of labor, if not also indications of social unrest. For instance, the construction of Monks Mound seems to have ceased by the end of the early Stirling phase (about A.D. 1150) and most other mounds with known construction dates have only Stirling- and not Moorehead-phase construction fills (Pauketat 2004; Reed et al. 1968). Even more important, at about A.D. 1150, the first of several 3-km-long 20 $\mathrm{ft}$-high palisade walls was constructed around Monks Mound and the Grand Plaza (Iseminger et al. 1990). Similar walls probably went up elsewhere in the region, with the East St. Louis site being the best documented instance (Pauketat 2005).

In any event, the remaining Mississippians appear to have left the Cahokia area during the late thirteenth and early- fourteenth centuries; no Mississippian cemetery is known to post-date A.D. 1300 (Emerson and Hargrave 2000; Emerson et al. 2003). Moreover, the abandonment of Cahokia was not an isolated phenomena. By the end of the fourteenth century, the fortified centers and their support settlements around the Ohio-Mississippi river confluence were also abandoned (Cobb and Butler 2002; Williams 1990).

\section{Climate Change and its Impact on the Cahokian Polity}

Recently, Cook et al. (2004) published summer (June-July-August) Palmer Drought Severity Index (PDSI) values for gridded locations across much of North America. The PDSI value is a measure of available soil moisture calculated from monthly temperature and precipitation. Negative PDSI values indicate dry conditions, whereas positive values indicate wet conditions. This index was specifically designed to evaluate drought impacts on agriculture (Palmer 1965); PDSI values range from -6 (extreme drought) to +6 (extreme wet).

The drought reconstructions are based on a 286point grid of instrumental PDSIs. The tree-ring net- work used for PDSI reconstruction over North America originally was initially composed of 835 annually resolved records. A revised network containing 1,825 records is now available and has been used in this paper. The PDSI data used in this paper were calibrated using a point-by-point regression of prewhitened instrumental PDSI data against treering records for the period 1928-1978 (Cook et al. 2007).

In a nested reconstruction procedure, the PDSI reconstructions are progressively pushed back in time by dropping out shorter series. This method of extending the reconstructions back in time was evaluated in detail by Cook et al. (2004) in their "Supporting Online Material" and was found to work well over the full 286-point grid. The Table 2 results for grid points 209 and, especially, 210 strongly support the validity of the nested reconstruction procedure described in the SOM. In Table 2 , the relevant models for grid points 209 and 210 for the Lohmann and Stirling phases (A.D. 1050-1200) are indicated. IFYR is the first year of each model and NTR is the number of tree-ring chronologies available for that model. RSQ is the calibrated variance (1928-1978 calibration period) and CVRE is the cross-validation (leave one out) reduction of error in the calibration period. Both parameters decrease as the number of chronologies decrease; however, all are significant at $p<.01$. For the 1900-1927 verification test period (data withheld from the calibration exercise), $R^{2}$ (square of the Pearson correlation), RE (reduction of error), and CE (coefficient of efficiency) are used. All are positive and highly significant $(p<.01)$. These verification tests are highly rigorous measures of reconstruction "accuracy" and as such indicate that the reconstructions are likely to have significant "hindcast" skill in the pre- 1200 period. The strength of this skill is of course not perfect, but its level is comparable to other high-quality drought and streamflow reconstructions developed from tree rings for this region (e.g., Blasing and Duvick 1984; Stahle and Cleaveland 1992, 1994). The comparability of RE and CE with RSQ for grid point 210 also indicates that the reconstruction is excellent in quality and nearly equal in strength over time. Grid point 209 is less so, but still significant (see Cook et al. [2004, 2007] for details of the PDSI reconstructions).

Two PDSI records, one at $90^{\circ} \mathrm{W} 37.5^{\circ} \mathrm{N}$ (site 
Table 2. Calibration and Verification Statistics for Tree-Ring-Based PDSI Reconstructions

\begin{tabular}{lccccccc}
\hline & FYR & NTR & RSQ & CVRE & $R^{2}$ & RE & CE \\
\hline GRID POINT 209 & 1190 & 3 & .450 & .415 & .406 & .199 & .198 \\
& 1140 & 2 & .342 & .280 & .333 & .164 & .164 \\
GRID POINT 210 & 920 & 1 & .299 & .237 & .275 & .174 & .173 \\
& 1190 & 7 & .524 & .485 & .614 & .542 & .542 \\
& 1150 & 6 & .492 & .450 & .637 & .593 & .593 \\
& 1140 & 6 & .492 & .450 & .637 & .593 & .593 \\
& 1020 & 3 & .385 & .340 & .669 & .637 & .637 \\
& 1000 & 2 & .297 & .246 & .524 & .441 & .441 \\
& 920 & 1 & .240 & .178 & .264 & .170 & .170 \\
\hline
\end{tabular}

FYR = first year of each model; NTR = number of tree-ring chronologies; RSQ = calibrated variance of the 1928-1978 calibration period; $\mathrm{CVRE}=$ cross-validation reduction of error; $R^{2}=$ square of the Pearson correlation; $\mathrm{RE}=$ reduction error; $\mathrm{CE}=$ coefficient of efficiency.

209) and the other at $90^{\circ} \mathrm{W} 40.0^{\circ} \mathrm{N}$ (site 210) (NOAA 2007) bracket Cahokia (Figure 2). The mean PDSI data for the two grid points are shown in Figure 3. Trees used in the PDSI constructions for sites 209 and 210 include Bald cypress (Taxodium distichum) and red cedar (Juniperus virginiana), whose growth are highly correlated with spring rainfall (see, e.g., Stahle and Cleaveland 1992).

The stacked (mean of the two data series) PDSI record indicates that the Lohmann phase was relatively wet, comparable to the wettest periods occurring during the past 1,000 years (Figure $3 a) .{ }^{2}$ On the other hand, the Stirling phase and the first half of the Moorehead phase were characterized by a series of droughts that increased in intensity and persistency during the subsequent 145 years (Figure 3b). Annual PDSI data indicate positive (wet) values for 28 out of 50 years during the Lohmann phase, 18 out of 50 years for the early Stirling phase, and only 11 out of 50 years for the late Stirling phase (Figure 3c). These data indicate that drought occurred frequently during the early Stirling phase and that it dominated the late Stirling phase.

The areal extent of the two multi-decadal droughts that followed the A.D. 1050-1100 wet period are shown in Figure 4. The average PDSI value for the past thousand years at grid points 209 and 210 (PDSI $=-0.4$ ) is used to form the boundary between wet and dry regions. The droughts recorded at grid points 209 and 210 were regional in extent and impacted much of the Midwest as well as major surface-water drainages that flow into and along the American Bottom. It is evident that west-central Illinois experienced severe drought 140 out of 145 years following A.D. 1100
(Figures 3 and 4).

In Figure 5, the PDSI record for west-central Illinois (Figure 5a) is compared with estimates of population change for downtown Cahokia and the Richland farming complex (Figure 5c). Also shown are approximate times of the initial construction and reconstruction of the palisade wall that surrounded Monks Mound and the Grand Plaza (Figure 5b).

According to current archaeological reconstructions, a major political upheaval occurred at Cahokia at the beginning of the Lohmann phase, involving a rapid ascendancy of a new form of centralized authority and political community (Pauketat 1997, 2004). During this "boom" period, political consolidation was accompanied by the immigration of several thousand individuals to downtown Cahokia and the surrounding countryside.

However, for Cahokia to grow, agricultural intensification or extensification must have occurred and, clearly, the environment, including climate, established the limits of intensification. Cahokians, or various affiliated farming populations, might have provided the impetus. In either case, one could argue that, to a first approximation, there were limits to the productive potential of the floodplain around Cahokia, particularly with regard to maize (see Milner 1998; Schroeder 1999). Given Pauketat and Lopinot's (1997) estimate that Cahokia contained between 10,200 and 15,300 people during the Lohmann phase, some and probably much of Cahokia's agricultural support might have come from outside the American Bottom (Pauketat 2004:106).

The Richland farming complex represents the most likely engine that drove Cahokia's agricultural 


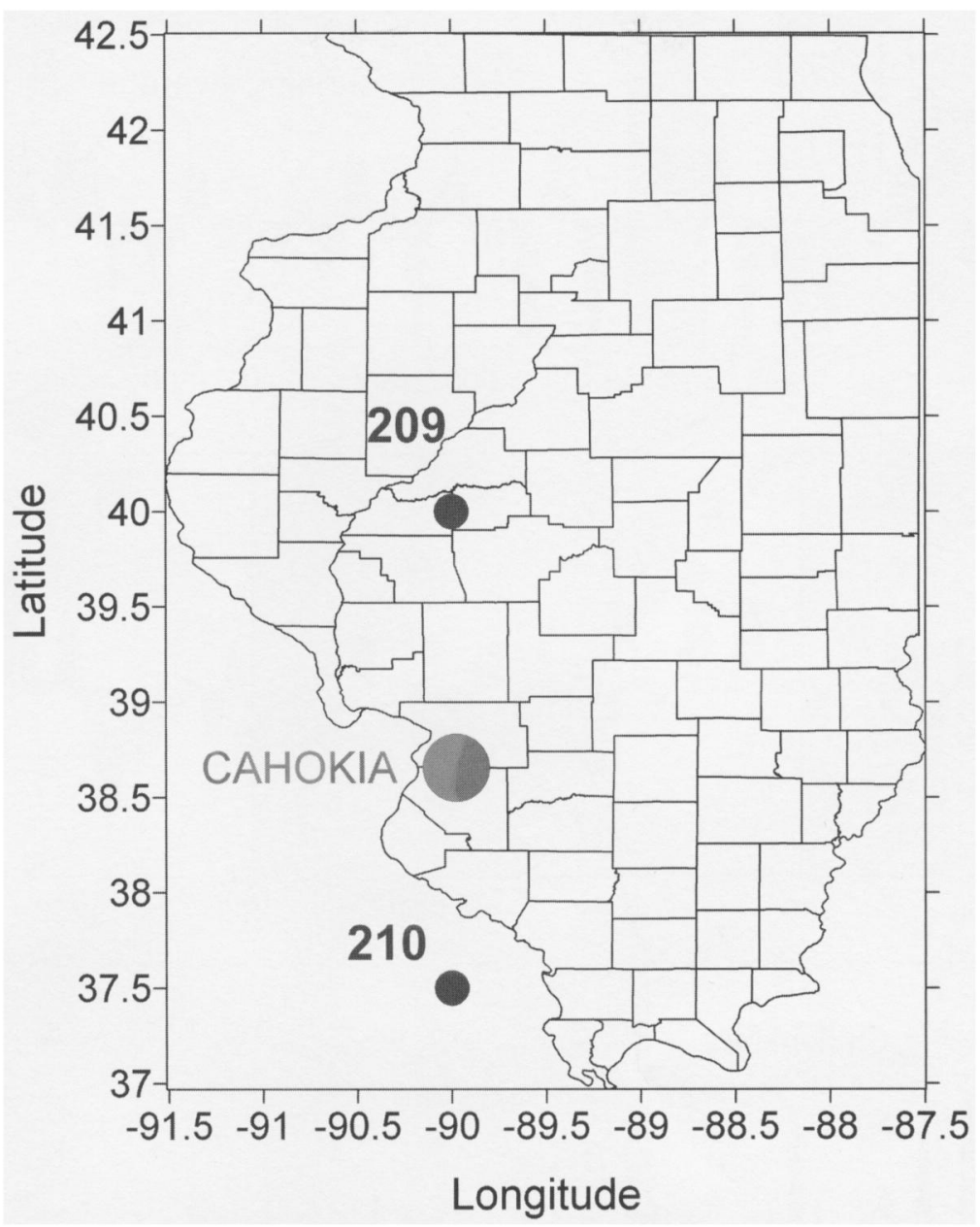

Figure 2. Locations of PDSI sites 209 and 210 relative to Cahokia.

reorganization of its countryside, doubtless supplemented by the produce of others districts within the American Bottom and beyond. Perhaps the reorganization of the American Bottom may also represent a response to wetter conditions that began before the Lohmann phase; i.e., increased precipitation and flooding of the Mississippi River and its side tributaries may have entailed a rise in the elevation of the local groundwater table. Shallow groundwater in the American Bottom will tend to be anoxic, given the high concentration of organic carbon in bottom sediments. Maize cannot survive in such an environment because its roots need oxygen. Thus, farmers may have moved to higher ground in response to the loss of well-drained agricultural bottomland.

Without the Richland complex, greater Cahokia might have been unable to absorb its Lohmann phase immigrant populations. Given above normal rainfall, the upland farming sites were probably able to provision Cahokia with a surplus of maize and other crops to use for ceremonial feasts or to fill central storehouses for later use (e.g., Pauketat et al. 2002).

The freeze-free growing season is typically long in what is now west-central Illinois (Joos 1960); therefore, maize production is mostly dependent on soil moisture during the growing season. In the Illinois highlands, soil moisture represents a balance between winter precipitation that encourages germination, summer precipitation that promotes plant growth, and evaporation / evapotranspiration that removes soil moisture during the growing season. The American Bottom may flood in the spring or 


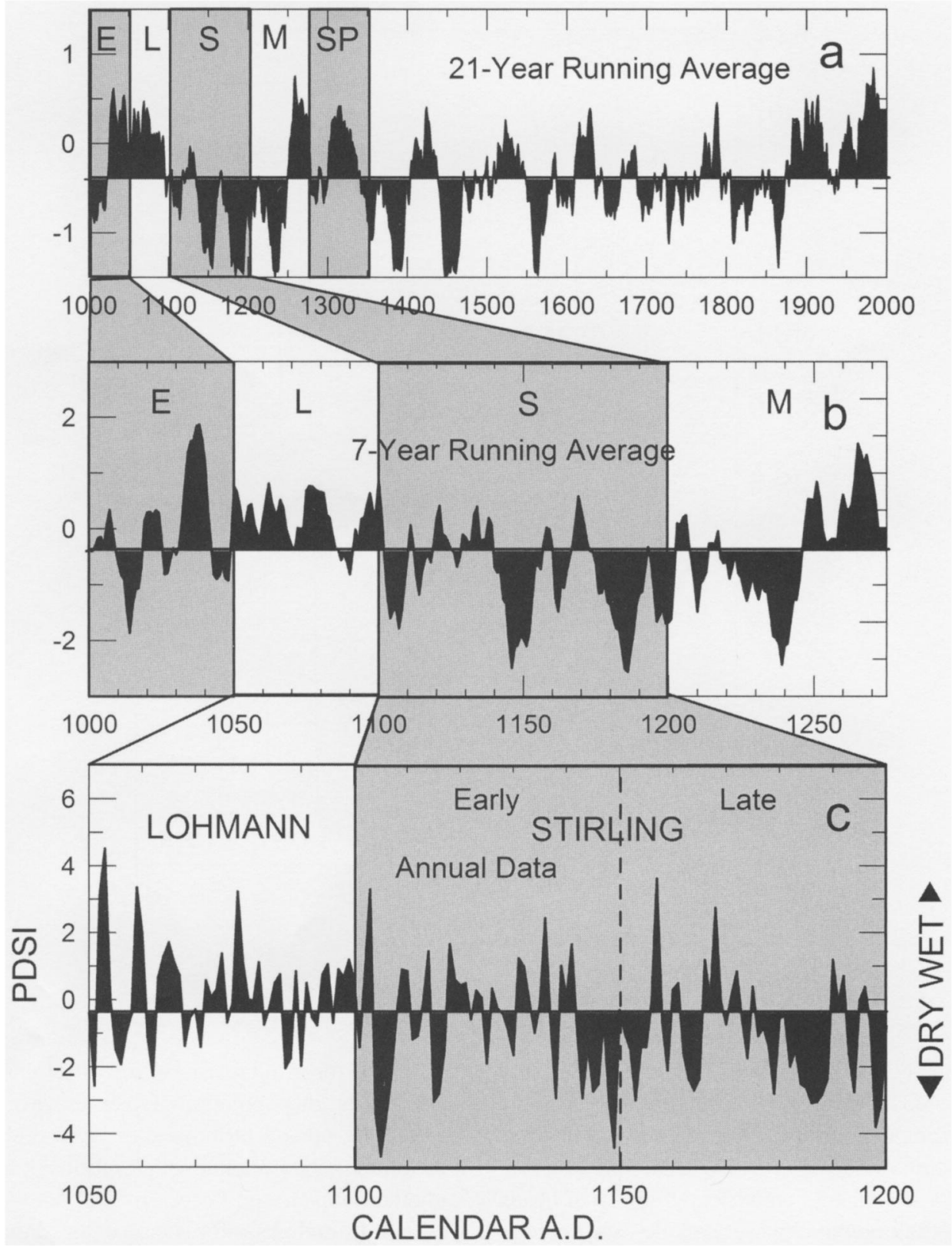

Figure 3. Tree-ring-based reconstructions of the Palmer Drought Severity Index (PDSI) for sites 209 and 210 (PDSI Site Map) bracketing the Cahokia area for the period (a) A.D. $1000-2000$, (b) A.D. 1000-1275, and (c) A.D. 1050-1200). A PDSI value of -.4 (mean value for last 1,000 years) was used to separate wet from dry periods. Positive values indicate wet conditions; negative values indicate drought conditions. $\mathrm{E}=$ pre-Mississippian Edelhardt phase, and $\mathrm{L}, \mathrm{S}, \mathrm{M}$, and SP = Mississippian Lohmann, Stirling, Moorehead, and Sand Prairie phases.

early summer, increasing soil moisture; however, additional summer rains are still needed for maize to reach maturity.

Beginning in the Stirling phase and continuing until about A.D. 1250, a series of intense droughts occurred that became more persistent with time (Figure 3a, b). We believe that abandonment of the Richland farming complex by about A.D. 1150 (Figure 5b) may be related to these droughts, and thus that the agricultural "glue" that held the 

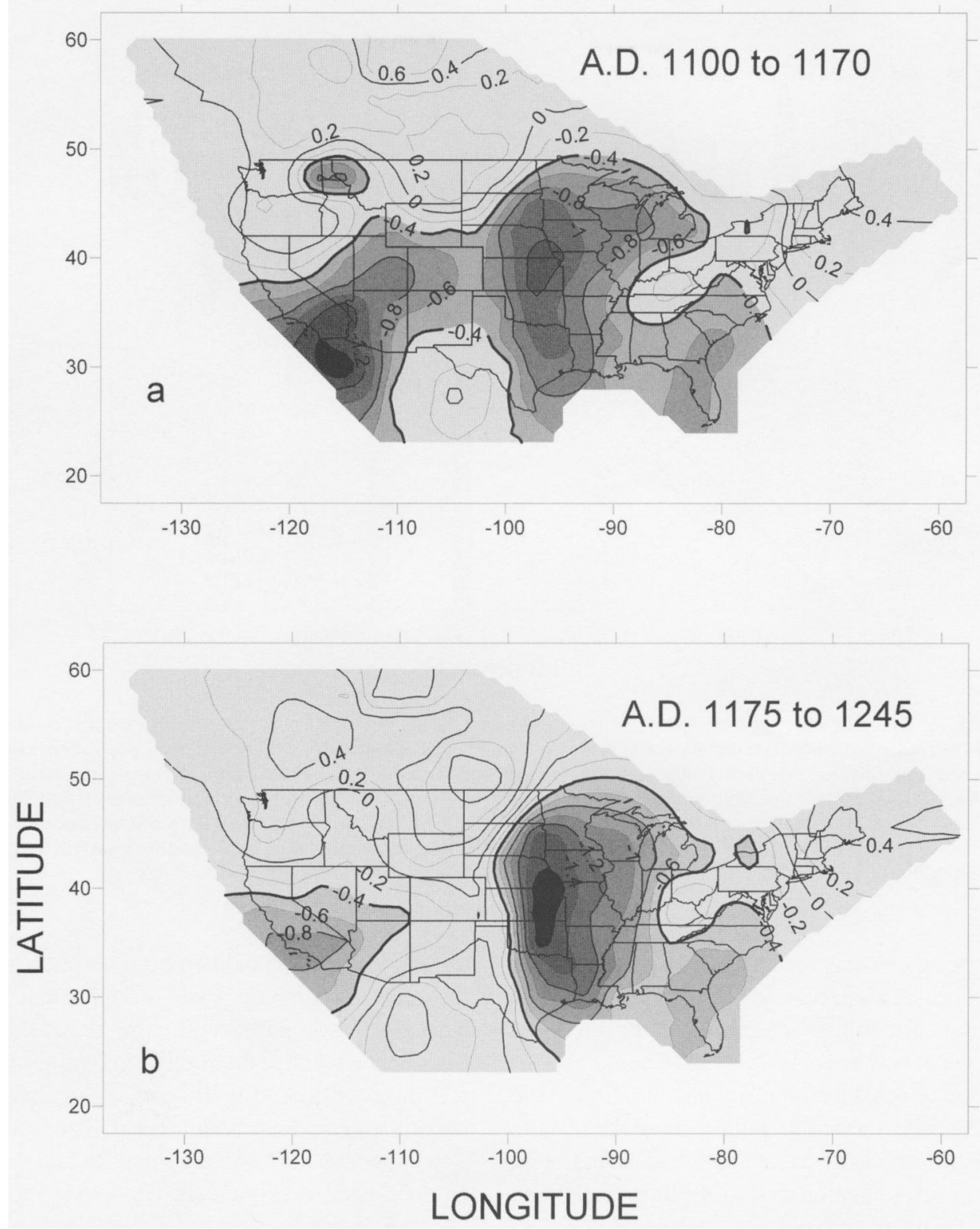

Figure 4. PDSI contour maps for two 70-year periods following A.D. 1100. A PDSI value of $\mathbf{- 0 . 4}$ (mean value for the period A.D. 1000 to 2000 ) is used to divide drought areas (medium gray to black) from relatively wet areas (light gray).

Cahokian polity together might have dissolved.

Cahokia's establishment and rapid expansion at the beginning of the Lohmann phase (Figure 5b) certainly evidences great organizational change and, perhaps, political will on the part of its founders. But whatever the factors that drew thousands of people to Cahokia (e.g., charismatic leadership, a religious cult, a more comfortable lifestyle, a Pax Cahokiana a' la Pauketat [2007]), immigrants and local laborers had to eat. In fact, a question remains as to whether the Cahokian leadership established a program of agricultural intensification or whether agricultural intensification was a consequence of the in-migration of people with previous agricultural experience.

The latter part of the Edelhardt phase (A.D. 1030-1040) was extremely wet (Figure 5a), and it may be that pre-Mississippian farmers in the Illi- 


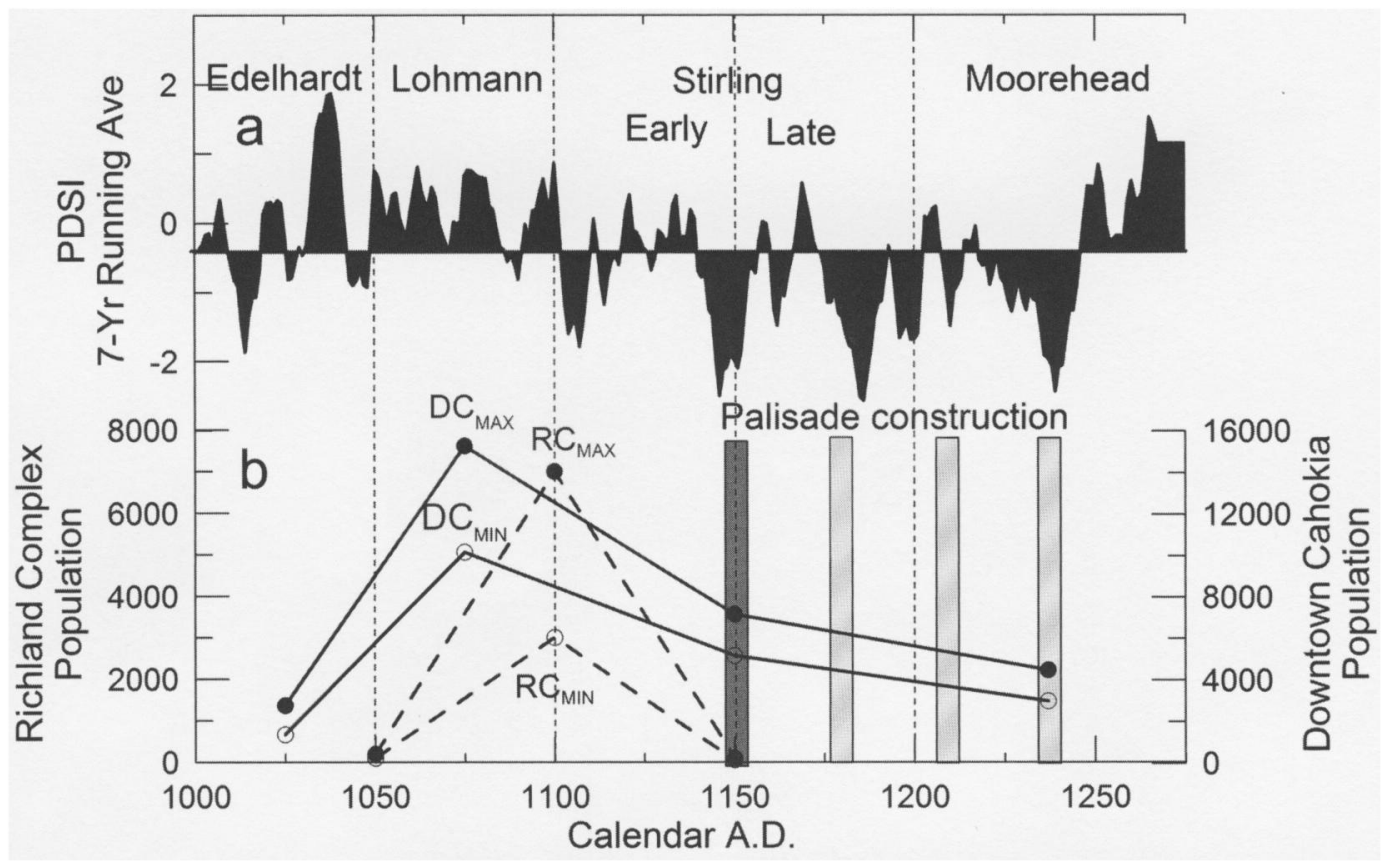

Figure 5. (a) A 7-year running average of the tree-ring-based PDSI record for sites 209 and 210 for the period A.D. 1000-1275 compared with (b) population estimates for Cahokia (Pauketat and Lopinot 1997), and population estimates for the Richland farming complex (Pauketat 2003). The vertical dotted lines indicate phase and intra-phase boundaries. The filled circles represent maximum population estimates and the open circles indicate minimum population estimates. Solid lines connect the population estimates for Downtown Cahokia (DC) and the dashed lines connect the population estimates for the Richland Complex (RC). The dark solid vertical rectangle indicates the initial construction of the Cahokian palisade and the lighter rectangles indicate schematically its subsequent reconstructions.

nois uplands were able to produce a series of good crops during that period, suggesting a location and procedure for future agricultural intensification. However, it was impossible for the Cahokian leadership to forecast the intensity and duration of the anomalously wet period that followed A.D. 1050 . We, therefore, suggest that continued immigration or localized population growth during the Lohmann phase might have been an iterative response to nearly continuous agricultural success experienced by local farmers, especially those moving into the Richland farming complex. That is, the expansion of productive upland farming was able to keep pace with immigration, encouraging the continued influx of individuals to greater Cahokia.

Between A.D. 1100 and 1245, when drought became the rule and not the exception, a population that had been farming upland tallgrass prairie met climate reality head on; the Richland farming complex was abandoned by A.D. 1150 (perhaps spurred by a severe 15-year-long drought, see Fig- ure 3c), leaving Cahokia without an integral part of its subsistence base. Even droughts that occur today decrease maize yields; the 1950s drought that affected much of the contiguous United States, including west-central Illinois, greatly reduced maize yields in both counties (Madison and St. Clair) in which the Cahokians and Richland farmers once resided (Figure 6). Obviously modernday maize production differs radically from Mississippian production; however, reduction in maize yields during drought in modern times serves to demonstrate the fragility of maize production even in the presence of improved technologies.

The loss of an integral part of its subsistence base need not have entailed a loss of control on the part of Cahokians during the relatively dry and agriculturally marginal early Stirling phase; but even if Cahokians attempted to maintain the social and political status quo, they would have done so in the face of people leaving Cahokia and, quite likely, the region surrounding Cahokia. 


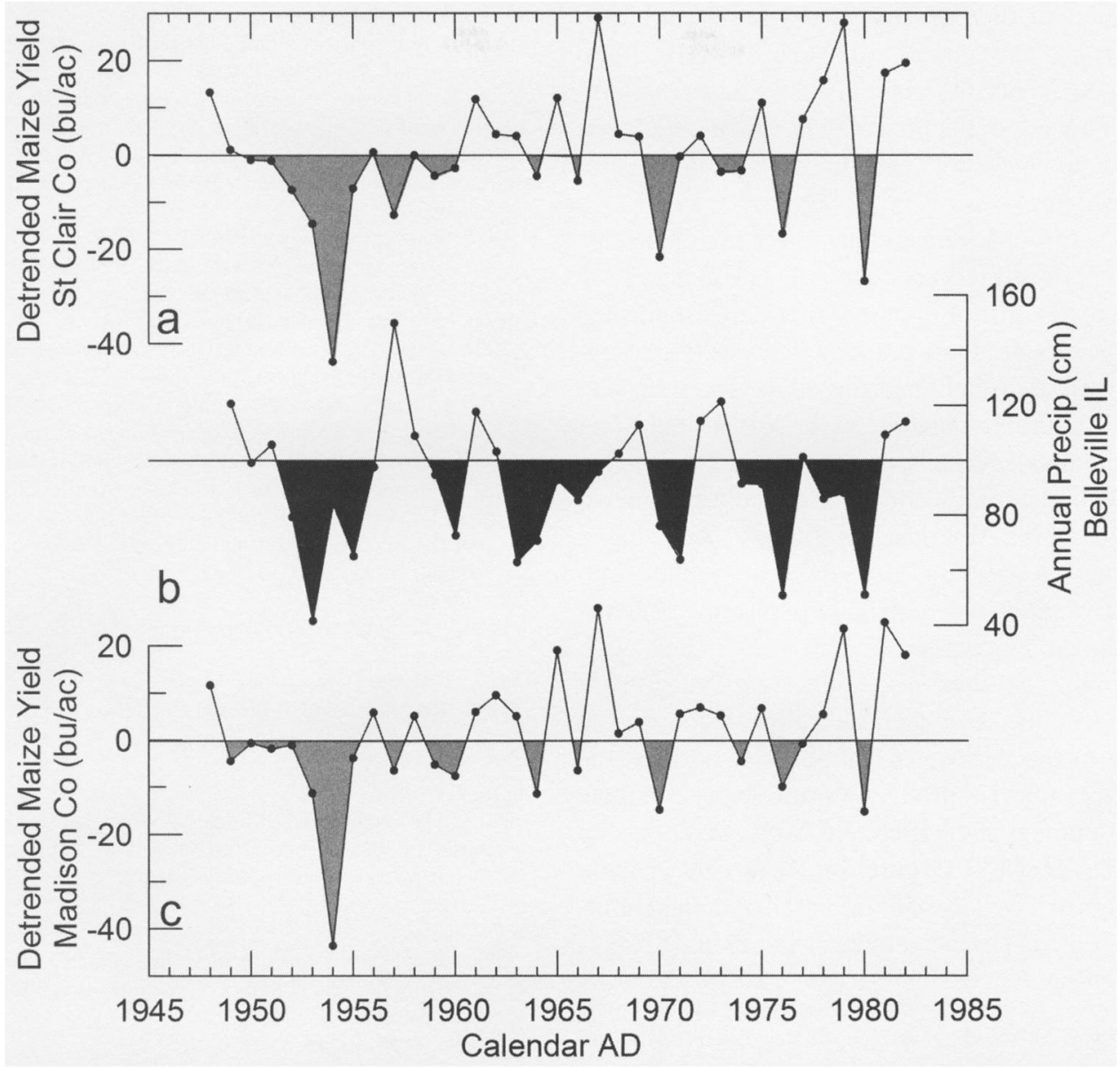

Figure 6. (a) Detrended maize yields for St. Clair county, Illinois; (b) annual precipitation received at Belleville, Illinois; and (c) detrended maize yields for Madison county, Illinois. Detrending was accomplished by fitting a second-degree polynomial to maize yields for the period 1918-2006. The detrending was done in order to remove the continuously increasing trend in maize productivity due to fertilization and the introduction of new maize hybrids. The time period displayed (1948-1982) was chosen to highlight the 1950s drought as well as less-intense droughts that occurred within the subsequent three decades. Gray-toned areas indicate times of drought and reduced maize yields.

\section{Conclusions}

Cahokia's cultural and demographic development between A.D. 1000 and 1300 was perhaps conditioned by a volatile climate. The latter part of the pre-Mississippian Edelhardt phase and the entire Lohmann phase were characterized by extremely wet conditions (Figure 5a). The population of downtown Cahokia increased from 1,400-2,800 people during the pre-Mississippian Edelhardt phase (A.D. 1000-1050) to 10,200-15,300 people during the early Mississippian Lohmann phase (A.D. 1050-1100 (Figure 5b). Between A.D. 1000 and 1100, American Bottom farmers moved to higher ground in an effort to avoid a rising groundwater table that was responding to anomalously high precipitation as well as to frequent flooding of the Mississippi River and its side tributaries. Midway through the century, a regional reorganization centered on Cahokia sealed the deal. While abundant precipitation may have diminished the agricultural potential of the American Bottom, it allowed the agricultural intensification of the Illinois uplands and the founding of the Richland farming complex (Figure 5b). In addition, the wet climate fed the marshlands, streams, sloughs, and lakes in the American Bottom, thereby increasing its fishery and further providing an environment 
conducive to the exploitation of wildfowl and small mammals. Thus, an overall increase in agricultural productivity and the fecundity of the American Bottom allowed for the rapid expansion of population in downtown Cahokia and in adjacent administrative centers.

A series of severe and persistent regional-scale droughts occurred between A.D. 1100 and 1245 (Figure 5a). Stirling-phase farms were established at low elevations in the American Bottom, suggesting that drought had caused the water table to fall. The rural population on the Mississippi River floodplain increased slightly during the Stirling phase, perhaps indicating that agricultural intensification of the American Bottom was occurring in response to drier conditions or because of the relocation of previously upland farmers down onto the floodplain. Fewer fish remains are associated with Stirling-phase sites, also suggesting that drought also led to the seasonal desiccation of sloughs and lakes in the American Bottom. But perhaps the greatest impact of drought was the nearly complete abandonment of the Richland farming complex by about A.D. 1150 (Figure 5b). Persistent drought appears to have led to the downfall of upland farming if not also to the demise of Cahokia.

Acknowledgments. The authors wish to thank Charles Cobb, Gregory Waselkov, Eugene Hattori, Ken Petersen, Howard Taylor, Gary Landis, and four anonymous reviewers for their comments and suggestions on earlier versions of this manuscript. Parts of the archaeological research used in this paper were funded by the National Science Foundation (BNS9305404, SBR 99-96169), National Geographic Society, Wenner-Gren Foundation for Anthropological Research, the Illinois Transportation Archaeological Research Program at the University of Illinois, and the Illinois Department of Transportation. All errors and omissions of fact are the sole responsibility of the authors.

\section{References Cited}

Alt, Susan M.

2000 Cahokian Change and the Authority of Tradition. In The Archaeology of Traditions: Agency and History before and after Columbus, edited by Timothy R. Pauketat, pp. 141-156. University Press of Florida, Gainesville.

2001 Identities, Traditions, and Diversity in Cahokia's Uplands. Midcontinental Journal of Archaeology 27:217-235.

2006 Cultural Pluralism and Complexity: Analyzing a Cahokian Ritual Outpost. Unpublished Ph.D. dissertation, Department of Anthropology, University of Illinois, Urbana-Champaign.

Anderson, David G., and KirkA. Maasch, Daniel H. Sandweiss, and Paul A. Mayewski

2007 Climate and Cultural Change: Exploring Holocene Transitions. In Climate Change and Cultural Dynamics: A Global Perspective on Mid-Holocene Transitions, edited by David G. Anderson, Kirk A. Maasch, and Daniel H. Sandweiss, pp. 1-23. Academic Press, London.

Anderson, David G., and David W. Stahle, and Malcolm M. Cleaveland

1995 Paleoclimate and the Potential Food Reserves of Mississippian Societies: A Case Study from the Savannah River Valley. American Antiquity 60:258-286.

Benson, Larry, and Kenneth Petersen, and John Stein

2007 Anasazi (Pre-Columbian Native-American) Migrations during the Middle- $12^{\text {th }}$ and Late- $13^{\text {th }}$ Centuries: Were They Drought Induced? Climatic Change 83:187-213.

Benson, Larry V., and Michael S. Berry, Edward A. Jolie, Jerry D. Spangler, David W. Stahle, and Eugene M. Hattori

2007 Possible Impacts of Early-11 ${ }^{\text {th }}-$, Middle-12 ${ }^{\text {th }}-$, and Late-13 ${ }^{\text {th }}$-Century Droughts on Western Native Americans and the Mississippian Cahokians. Quaternary Science Reviews 26:336-350.

Blake, Leonard W.

1955 The Lambert-St. Louis Airport site. The Missouri Archaeologist 17:27-39.

Blasing, T. J., and D. N. Duvick

1984 Reconstruction of Precipitation History in the North American Corn Belt Using Tree Rings. Nature 307:143-145.

Churmny, William W.

1973 The Ecology of the Middle Mississippian Occupation of the American Bottom. Unpublished Ph.D. dissertation, Department of Anthropology, University of Illinois, Urbana.

Cobb, Charles R.

2000 From Quarry to Cornfield: The Political economy of Mississippian Hoe Production. University of Alabama Press, Tuscaloosa.

Cobb, Charles R., and Brian M. Butler

2002 The Vacant Quarter Revisited: Late Mississippian Abandonment of the Lower Ohio Valley. American Antiquity 67:625-641.

Collins, James M.

1997 Cahokia Settlement and Social Structures as Viewed from the ICT-II. In Cahokia: Domination and Ideology in the Mississippian World, edited by Timothy R. Pauketat and Thomas E. Emerson, pp. 124-140. University of Nebraska Press, Lincoln.

Cook, Edward R., and Richard Seager, Mark A. Cane, and David W. Stahle

2007 North American Drought: Reconstructions, Causes, and Consequences. Earth-Science Reviews 81:93-134.

Cook, Edward R., and Connie A. Woodhouse, C. Mark Eakin, David M. Meko, and David W. Stahle

2004 Long-Term Aridity Changes in the Western United States. Science 306:1015-1018. Supporting Online Material accessed online at http://www.sciencemag.org/cgi/content/full/1102586/DC1)

Cross, Paula G.

1987 A Review of Faunal Procurement Strategies during the Late Woodland and Emergent Mississippian Transition. In The Emergent Mississippian, edited by Richard A. Marshall, pp. 9-21. Cobb Institute of Archaeology, Mississippi State University, Starkville.

Dalan, Rinita A., and George R. Holley, William I. Woods, Harold W. Watters, Jr., and John A. Koepke

2003 Envisioning Cahokia: A Landscape Perspective. 
Northern Illinois University Press, DeKalb.

Davidson, W.B., and J. L. Doughty, and J. L. Bolton

1941 Nitrate Poisoning of Livestock. Canadian Journal of Comparative Medicine 5:393-313.

Douglass, Andrew. E.

1929 The Secret of the Southwest Solved by Talkative Tree Rings. National Geographic Magazine 56:736-770.

Drysdale, Russell, and Giovanni Zanchetta, John Hellstrom, Roland Maas, Anthony Fallick, Matthew Pickett, Lan Cartwright, and Leonardo Piccini

2006 Late Holocene Drought Responsible for the Collapse of Old World Civilizations is Recorded in an Italian Cave Flowstone. Geology 34:101-104.

Emerson, Thomas E.

1992 The Mississippian Dispersed Village as a Social and Environmental Strategy. In Late Prehistoric Agriculture: Observations from the Midwest, edited by W. I. Woods, pp. 198-216. Illinois Historic Preservation Agency Studies in Illinois Archaeology 8, Springfield.

Emerson, Thomas E.

1997a Cahokia and the Archaeology of Power. The University of Alabama Press, Tuscaloosa.

1997b Reflections from the Countryside on Cahokian Hegemony. In Cahokia: Domination and Ideology in the Mississippian World, edited by Timothy R. Pauketat and Thomas E. Emerson, pp. 167-189. University of Nebraska Press, Lincoln.

Emerson, Thomas E., and Eve A. Hargrave

2000 Strangers in Paradise? Recognizing Ethnic Mortuary Diversity on the Fringes of Cahokia. Southeastern Archaeology 19, 1-23.

Emerson, Thomas. E., and Douglas. K. Jackson

1984 The BBB Motor Site (11-Ms-595). American Bottom Archaeology, FAI-270 Site Reports 6. University of Illinois Press, Urbana.

Emerson, Thomas E., and Eve A. Hargrave, and Kristin Hedman

2003 Death and Ritual in Early Rural Cahokia. In Theory, Method, and Technique in Modern Archaeology, edited by Robert J. Jeske and Douglas K. Charles, pp. 163-181 Praeger Publishers, Westport, Connecticut.

Fortier, Andrew C., and Thomas E. Emerson, and Dale L. McElrath

2006 Calibrating and Reassessing American Bottom Culture History. Southeastern Archaeology 25:170-211.

Gill, Richardson B.

2000 The Great Maya Droughts. University of New Mexico Press, Albuquerque.

Hargrave, Michael L., and Gerald A. Oetelaar, Neal H. Lopinot, Brian M. Butler, and Deborah A. Billings

1983 The Bridges Site 11-Mr-11: A Late Prehistoric Settlement in the Central Kaskaskia Valley. Center for Archaeological Investigations Research Paper 38. Southern Illinois University, Carbondale.

Harl, Joseph L.

1991 An Alternative Explanation for the Shift from a Late Woodland to a Mississippian Lifestyle Based on Evidence from the Bridgeton Site (23SL442) and Other Sites along the Lower Missouri River Valley. Unpublished Masters Thesis, Department of Anthropology, Washington University, St. Louis, Illinois.

Hodell, David A., Jason H. Curtis, and Mark Brenner

1995 Possible Role of Climate in the Collapse of Classic Maya Civilization. Science 375:391-394.

Holley, George R.

2006 Perspectives from the Edge of Looking Glass Prairie:
The Scott Joint-Use Archaeological Project. Southeastern Archaeology 25:301-328.

Hunt, William J., Jr.

1974 Late Woodland-Mississippian Relationships at the River Bend East Site (23SL70), St. Louis County, Missouri. Unpublished Masters Thesis, University of Nebraska, Lincoln.

Iseminger, William R., and Timothy R. Pauketat, Brad Koldehoff, Lucretia S. Kelly, and Leonard Blake

1990 The Archaeology of the Cahokia Palisade, Part I. East Palisade Excavations. Illinois Cultural Resource Study 14. Illinois Historical Preservation Agency, Springfield.

Johannessen, Sissel

1984 Paleoethnobotany. In American bottom Archaeology, edited by Charles J. Bareis and James W. Porter, pp. 197-214. University of Illinois Press, Urbana.

Jones, Terry L., and Gary M. Brown, L. Mark Raab, Janet L. McVickar, W. Geoffrey Spaulding, Douglas J. Kennett, Andrew York, and Phillip L. Walker

1999 Environmental Imperatives Reconsidered: Demographic Crises in Western North America during the Medieval Climatic Anomaly. Current Anthropology 40:137-170.

Joos, Lothar A.

1960 Freeze Probabilities in Illinois. University of Illinois Agricultural Experiment Station Bulletin 650, Urbana.

Judge, W. James

1989 Chaco Canyon-San Juan Basin. In Dynamics of Southwest Prehistory, edited by Linda S. Cordell and George J. Gumerman, pp. 209-261. Smithsonian Institution Press, Washington, D.C.

Kelly, John E.

1990 The Emergence of Mississippian Culture in the American Bottom Region. In The Mississippian Emergence, edited by Bruce D. Smith, pp. 113-152. Smithsonian Institution Press, Washington, D.C.

Kelly, Lucretia S.

1990 Range Phase Faunal Analysis. In The Range Site 2: The Emergent Mississippian Dohack and Range Phase Occupations, by John E. Kelly, Steven J. Ozuk, and Joyce A. Williams, pp. 487-551. University of Illinois Press, Urbana.

Kelly, Lucretia S.

1997 Patterns of Faunal Exploitation at Cahokia. In Cahokia: Domination and Ideology in the Mississippian World, edited by Timothy R. Pauketat and Thomas E. Emerson, pp. 69-88. University of Nebraska Press, Lincoln.

Kelly, Lucretia S., and Paula G. Cross

1984 Zooarchaeology. In America Bottom Archaeology, edited by Charles J. Bareis and James W. Porter, pp. 215-232. University of Illinois Press, Urbana.

Kennett, Douglas J., and James P. Kennett

2006 Sea levels, Shorelines, Climate Change, and Cultural Evolution in Southern Mesopotamia. Journal of Island \& Coastal Archaeology 1:39-71.

Koldehoff, Brad

1989 Cahokia's Immediate Hinterland: The Mississippian Occupation of Douglas Creek. Illinois Archaeology 1:39-68.

Kuttruff, L. Carl

1972 The Marty Coolidge Site, Monroe County, Illinois. Southern Illinois Studies 10. Southern Illinois University, Carbondale.

Lopinot, Neal H., and Michael D. Conner, Jack H. Ray, and Jeffrey K. Yelton 
1998 Prehistoric and Historic Properties on Mitigation Lands, Horseshoe Lake Peninsula, Madison County, Illinois. St. Louis District Historic Properties Management Report No. 55, U.S. Army Corps of Engineers, St. Louis, Illinois.

Maher, Thomas O.

1989 Radiocarbon Dates. In The Holding Site: A Hopewell Community in the American Bottom, edited by Andrew C. Fortier, Thomas O. Maher, Joyce A. Williams, Michael C. Meinkoth, Kathryn E. Parker, and Lucretia S. Kelly, pp. 483-488. American Bottom Archaeology, FAI-270 Site Reports Vol. 19. University of Illinois Press, Urbana.

Mayo, Nelson S.

1895 Cattle Poisoning by Nitrate of Potash. Kansas Agricultural Experimental Station Bulletin 49:3-11.

Mehrer, Mark W.

1995 Cahokia's Countryside: HouseholdArchaeology, Settlement Patterns, and Social Power. Northern Illinois University Press, DeKalb.

Mehrer, Mark W., and James M. Collins

1995 Household Archaeology at Cahokia and in Its Hinterlands. In Mississippian Communities and Households, edited by J. Daniel Rogers and Bruce D. Smith, pp. 32-57. University of Alabama Press, Tuscaloosa.

Milner, George R.

1986 Mississippian Period Population Density in a Segment of the Central Mississippi Valley. American Antiquity 51:227-238.

Milner, George R.

1998 The Cahokia Chiefdom: the Archaeology of a Mississippian Society. Smithsonian Institution Press, Washington, D.C.

Milner George R., and Thomas E. Emerson, Mark W. Mehrer, Joyce A. Williams, and Duane Esary

1984 Mississippian and Oneota Period. In American Bottom Archaeology, edited by Charles J. Bareis and James W. Porter, pp. 158-186. University of Illinois Press, Urbana.

Milner, George R., and James S. Oliver

1999 Late Prehistoric Settlements and Wetlands in the Central Mississippi Valley. In Settlement Pattern Studies in the Americas: Fifty Years Since Virú, edited by Brian R. Billman and Gary M. Feinman, pp. 79-95. Smithsonian Institution Press, Washington, D.C.

National Oceanic and Atmospheric Administration

2007 National Climatic Data Center, World Data Center for Paleoclimatology, Drought Atlas PDSI ReconstructionsTime Series Plots, Electronic Data. http:/www.ncdc.noaa.gov/paleo/newpdsi.html.

Palmer, Wayne C.

1965 Meteorological Drought. U.S. Department of Commerce Research Paper No. 45, Washington, D.C.

Pauketat, Timothy R.

1994 The Ascent of Chiefs: Cahokia and Mississippian Politics in Native North America. University of Alabama Press, Tuscaloosa.

1997 Cahokian Political Economy. In Cahokia: Domination and Ideology in the Mississippian World, edited by Timothy R. Pauketat and Thomas E. Emerson, pp. 30-51. University of Nebraska Press, Lincoln.

1998a Refiguring the Archaeology of Greater Cahokia. Journal of Archaeological Research 6:45-89.

1998b The Archaeology of Downtown Cahokia: The Tract $15 A$ and Dunham Tract Excavations. Illinois Transportation Archaeological Research Program, Studies in Archaeology 1 . University of Illinois, Urbana.
2000 Politicization and Community in the Pre-Columbian Mississippian Valley. In The Archaeology of Communities: A New World Perspective, edited by Marcello A. Canuto and Jason Yaeger, pp. 16-43. Routledge, London.

2003 Resettled Farmers and the Making of a Mississippian Polity. American Antiquity 68:39-66.

2004 Ancient Cahokia and the Mississippians. Cambridge University Press, Cambridge, UK.

2005 The Archaeology of the East St. Louis Mound Center: Part 1-Southside Excavations, edited by Timothy R. Pauketat with contributions by Kristin Hedman, John E. Kelly, Lucretia S. Kelly, Kathryn E. Parker, and Timothy R. Pauketat. Illinois Transportation Archaeological Research Program Report of Investigation. University of Illinois, Urbana.

2007 Chiefdoms and Other Archaeological Delusions. AltaMira Press, Plymouth, United Kingdom.

Pauketat, Timothy R., and Neal H. Lopinot

1997 Cahokian Population Dynamics. In Cahokia: Domination and Ideology in the Mississippian World, edited by Timothy R. Pauketat and Thomas E. Emerson, pp. 103-123. University of Nebraska Press, Lincoln.

Pauketat, Timothy R., Mark A. Rees, and Stephanie L. Pauketat

1998 An Archaeological Survey of the Horseshoe Lake State Park, Madison County, Illinois. Illinois State Museum Reports of Investigations 55. Illinois State Museum, Springfield.

Pauketat, Timothy R., and Lucretia S. Kelly, Gayle J. Fritz, Neal H. Lopinot, Scott Elias, and Eve Hargrave

2002 The Residues of Feasting and Public Ritual at Early Cahokia. American Antiquity 67:257-279.

PDSI Site Map

2009 Electronic document, http://www.ncdc.noaa.gov/ paleo/newpdsi.html

Reed, Nelson A., and John W. Bennett, and James W. Porter 1968 Solid Core Drilling of Monks Mound: Technique and Findings. American Antiquity 33:137-148.

Riley, Thomas J., and Gregory R. Walz, Charles J. Bareis, Andrew C. Fortier, and Kathryn E. Parker

1994 Accelerator Mass Spectrometry (AMS) Dates Confirm Early Zea Mays in the Mississippi River Valley. American Antiquity 59:490-498.

Rindos, David, and Sissel Johannessen

1991 Human-Plant Interactions and Cultural Change in the American Bottom. In Cahokia and the Hinterlands, edited by Thomas E. Emerson and R. Barry Lewis, pp. 35-45. Prehistory Press, Madison, Wisconsin.

Scarry, C. Margaret

1993a Agricultural Risk and the Development of the Moundville Chiefdom. In Foraging and Farming in the Eastern Woodlands, edited by C. Margaret Scarry, pp. 157-181. Ripley P. Bullen Series, University Press of Florida, Gainesville.

1993b Variability in Mississippian Crop Production Strategies. In Foraging and Farming in the Eastern Woodlands, edited by C. Margaret Scarry, pp. 78-90. Ripley P. Bullen Series, University Press of Florida, Gainesville.

Schroeder, Sissel

1999 Maize Productivity in the Eastern Woodlands and Great Plains of North America. American Antiquity 64:499-516.

2004 Power and Place: Agency, Ecology, and History in the American Bottom, Illinois. Antiquity 78:812-827.

Stahle, David W., and Malcolm K. Cleaveland

1992 Reconstruction and analysis of spring rainfall over the 
southeastern U.S. for the past 1000 years. Bulletin of the American Meteorology Society 73:1947-1961.

Stahle, David W., and Malcolm K. Cleaveland

1994 Tree-ring Reconstructed Rainfall Over the Southeastern U.S.A. during the Medieval Warm Period and Little Ice Age. Climatic Change 26: 199-212.

Stahle, David W., and Edward R. Cook, Malcolm K. Cleaveland, Matthew Therrell, David Meko, Henri GrisșinoMayer, Emma Watson, and Brian Luckman

2000 Tree-ring Data Document 16th Century Megadrought over North America. Eos: Transactions of the American Geophysical Union 81(21):121-125.

Sussenbach, Tom

1993 Agricultural Intensification and Mississippian Development in the Confluence Region of the Mississippi River Valley. Unpublished Ph.D. dissertation, Department of Anthropology, University of Illinois, Urbana.

Sutton, Robert P.

1860 The Prairie State. A Documentary History of Illinois: Colonial Years to 1860. William B. Eerdmans Publishing Company, Grand Rapids, Michigan.

Welch, L. Fred

1979 Nitrogen Use and Behavior in Crop Production. Illinois Agricultural Experiment Station Bulletin 761, Urbana.

Williams, Stephen

1990 The Vacant Quarter and Other Late Events in the Lower Valley. In Towns and Temples Along the Mississippi, edited by David H. Dye and Cheryl Cox, pp. 170-180. University of Alabama Press, Tuscaloosa.

\section{Notes}

1. There are differences in the population estimation procedures, but it is possible to reconcile the two estimates cited here. Pauketat and Lopinot (1997) use the commonly accepted duration of 50 years for the Lohmann phase and believe 10 years to have been a minimum average uselife for houses at Cahokia; Milner (1998:123) assumes a centurylong duration for the Lohmann phase and considers 10 years a maximum house-duration estimate. More recently, Pauketat (2003) argued that both the 50-year phase length and the 10year building-duration estimates best fit the archaeological evidence of numbers of domiciles and their rates of reconstruction at Cahokia and other excavated sites in the region. In the end, if we alter Milner's Lohmann phase duration to 50 years, there is "substantial agreement" between these two estimates (Pauketat 2003:47).

2. The boundaries between archaeological phases are not nearly as precise as the tree-ring-based reconstructions of the PDSI which are accurate to one year. However, the timing of the phase boundaries and the durations of the phases are generally accepted by Mississippian scholars and may be accurate to \pm 25 years.

Submitted September 3, 2007; Revised August 1, 2008; Accepted May 18, 2009. 